ISSN : 2303-1514 | E-ISSN : 2598-5949

\title{
THE INTERNALIZATION OF “MARI BUANG SAMPAH PADA TEMPATNYA" (MARBUNGSAMTEM) PROGRAM TO THE CHARACTER OF ENVIRONMENTAL CARE AT SDN TAMAN CIRUAS PERMAI
}

\author{
Kiki Rizky Amalia ${ }^{1}$, Ujang Jamaludin ${ }^{2}$, Encep Andriana ${ }^{3}$ \\ ${ }^{1,2,3}$ Universitas Sultan Ageng Tirtayasa, Banten, Indonesia. \\ ${ }^{1}$ kikirizamalia@gmail.com, ${ }^{2}$ ujangjamaludin@untirta.ac.id, ${ }^{3}$ andriana118@untirta.ac.id

\section{INTERNALISASI PROGRAM MARI BUANG SAMPAH PADA TEMPATNYA TAMAN CIRUAS PERMAI} \\ (MARBUNGSAMTEM) TERHADAP KARAKTER PEDULI LINGKUNGAN DI SDN
}

\section{ARTICLE HISTORY}

Submitted:

10 Juni 2021

$10^{\text {th }}$ June 2021

Accepted:

04 September 2021

$04^{\text {th }}$ September 2021

Published:

28 Oktober 2021

$28^{\text {th }}$ October 2021

\section{ABSTRACT}

Abstract: This study aimed to see the internalization of "Mari Buang Sampah Pada Tempatnya" (Marbungsamtem) Program at SDN Taman Ciruas Permai. This research used a descriptive qualitative research method. Data were collected through interview, observation, and documentation. Interviews were conducted with the principal, teachers, and parents of students. Observations were made in two places, namely environment SDN Taman Ciruas Permai and the students' housing environment of Taman Ciruas Permai. Meanwhile, the documentation was carried out at the time of pre-research and research. This documentation was done when the interview was finished at school as well as at students' homes during the observation activities as well as doing research documentation. The results of this study indicated that: (1) the process of internalizing "Mari Buang Sampah Pada Tempatnya" (Marbungsamtem) Program to the character of environmental care was implemented in two stages, namely planning and implementation. (2) factors inhibiting and supporting the internalization of "Mari Buang Sampah Pada Tempatnya" (Marbungsamtem) Program to the character of environmental care came from the school environment and the home environment of students.

Keywords: character education, character of environmental cares

Abstrak: Penelitian ini bertujuan untuk mengetahui internalisasi program mari buang sampah tempatnya (Marbungsamtem) terhadap karakter peduli lingkungan di SDN Taman Ciruas Permai. Penelitian ini menggunakan metode penelitian deskriptif kualitatif.. Teknik pengumpulan data menggunakan teknik wawancara, observasi, dan dokumentasi. Wawancara dilakukan dengan narasumber kepala sekolah, guru, dan orang tua siswa. Observasi dilakukan di dua tempat yaitu Lingkungan SDN Taman Ciruas permai dan Lingkungan rumah siswa perumahan Taman Ciruas Permai. Sedangkan dokumentasi dilakukan pada saat pra penelitian dan penelitian. Dokumentasi ini dilakukan ketika selesai melakukan wawancara di sekolah maupun rumah siswa. Selain itu, saat kegiatan observasi peneliti sekaligus melakukan dokumentasi penelitian. Hasil dari penelitian ini menunjukkan bahwa: (1) proses internalisasi program mari buang sampah pada tempatnya (Marbungsamtem) terhadap karakter peduli lingkungan dilaksanakan melalui dua tahap yakni perencanaan dan pelaksanaan. (2) Faktor penghambat dan pendukung dalam internalisasi program mari buang sampah pada tempatnya (Marbungsamtem) terhadap karakter peduli lingkungan. Faktor penghambat dan pendukung berasal dari lingkungan sekolah dan lingkungan rumah siswa.

Kata Kunci: pendidikan karakter, karakter peduli lingkungan

\section{CITATION}

Amalia, K. R., Jamaludin, U., \& Andriana, E. (2021). The Internalization of "Mari Buang Sampah Pada Tempatnya" (Marbungsamtem) Program to the Character of Environmental Care at SDN Taman Ciruas Permai. Primary: Jurnal Pendidikan $\begin{array}{lllll}\text { Guru Sekolah Dasar, } & 10 & \text { (5), } & \text { 1338-1346. } & \text { DOI }\end{array}$ http://dx.doi.org/10.33578/jpfkip.v10i5.8277. 


\section{PENDAHULUAN}

Secara mendasar, kehidupan manusia tidak terlepas dari lingkungan. Lingkungan merupakan suatu tempat yang dihuni oleh makhluk hidup untuk melakukan segala aktifitasnya. Menurut Tatang (2012:153), Lingkungan merupakan ruang dan waktu yang menjadi tempat eksistensi manusia. Dalam konsep ajaran pendidikan, lingkungan yang baik adalah lingkungan yang kondusif dan strategis untuk melaksanakan proses pembelajaran.

Lingkungan yang bersih dan terawat akan membuat kita menjadi nyaman untuk berada di tempat tersebut. Sebaliknya, apabila lingkungan kotor dan tidak terawat maka kita tidak akan nyaman untuk berada di tempat tersebut. Kesadaran akan lingkungan ini perlu segera dibentuk pada setiap orang. Menciptakan lingkungan belajar yang bersih dapat dilakukan dengan cara menanamkan karakter peduli lingkungan pada siswa di sekolah. Terdapat sekolah di Indonesia yang kurang peduli terhadap lingkungan disekitarnya dan tidak memiliki sarana dan prasarana yang mendukung untuk menciptakan sekolah yang memiliki lingkungan yang bersih, salah satunya yaitu SDN Taman Ciruas Permai. Namun pada tahun 2018 SD tersebut membentuk sebuah program yang bertujuan menciptakan lingkungan di SD tersebut menjadi lingkungan yang bersih dan terawat. Program tersebut dinamai dengan Mari Buang Sampah Pada Tempatnya (Marbungsamtem). Program ini dilakukan dengan cara membawa kantung plastik sampah dari rumah untuk membuang sampahnya saat di sekolah, kemudian sampah tersebut di bawa pulang ke rumah untuk di buang. Selain itu, saat istirahat siswa dilarang untuk makan di dalam kelas. Hal ini dilakukan agar siswa tidak menyimpan sampah makanannya di dalam kolong meja kelas.

Namun saat ini kegiatan pembelajaran tidak bisa dilakukan secara tatap muka ataupun langsung tetapi secara online. Hal ini dikarenakan sedang adanya pandemi covid 19 yang mengharuskan seluruh siswa sekolah tidak bisa melakukan pembelajaran secara langsung di sekolah. Pembelajaran secara online dilaksanakan mulai dari bulan Maret 2020. Oleh karena itu proses dalam pembentukan karakter peduli lingkungan pada diri siswa pun dapat dilakukan di lingkungan rumah siswa. Melalui pembiasaan yang ada di dalam program sekolah maka pembiasaan tersebut dapat diterapkan di lingkungan rumah siswa. Oleh karena itu pembiasaan peduli terhadap lingkungan yang di lakukan di dalam sekolah dapat di lakukan di dalam lingkungan rumah.

\section{KAJIAN TEORI}

Internalisasi merupakan suatu proses penanaman sikap yang telah dilakukan dan melekat dalam diri seseorang yang didapatkan melalui pembinaan atau bimbingan seseorang. Menurut Ihsan, Fuad (2010: 155) Internalisasi merupakan upaya yang dilakukan untuk memasukkan nilai-nilai ke dalam jiwa sehingga menjadi miliknya.

Menurut Ahmad, T (2010: 229) Internalisasi sebagai upaya memberikan pengetahuan, keterampilan ke dalam diri pribadi seseorang. Dalam hal ini istilah yang umum dikenal dengan aspek kognitif, psikomotorik, dan afektif. 
Berdasarkan pendapat tersebut dapat disimpulkan bahwa internalisasi merupakan suatu upaya yang dilakukan dengan cara memberikan pengetahuan dan keterampilan, selanjutnya pengetahuan dan keterampilan tersebut dapat di praktikan pada situasi yang berbeda berupa sikap yang baik.

\section{Karakter Peduli Lingkungan}

Karakter peduli lingkungan merupakan sebuah sikap atau perilaku yang menunjukkan peduli terhadap lingkungan disekitarnya. Kepedulian terhadap lingkungan yang dimilikinya bukan dari paksaan orang lain, melainkan berasal dari hati nurani diri sendiri.

$$
\text { Menurut Yaumi (2014:111), }
$$

karakter peduli lingkungan adalah sikap dan tindakan yang berupaya mencegah kerusakan alam di lingkungan alam sekitarnya, dan mengembangkan upayaupaya untuk memperbaiki kerusakan alam yang sudah terjadi.

Menurut Komalasari Kokom (2017:9) peduli lingkungan meupakan sikap dan tindakan yang selalu berupaya mecegah kerusakan pada lingkungan alam di sekitarnya, dan mengembangkan upayaupaya untuk memperbaiki kerusakan alam yang sudah terjadi.

Berdasarkan pendapat beberapa para ahli, dapat disimpulkan bahwa karakter peduli lingkungan merupakan suatu perilaku atau sikap seseorang yang berupaya untuk menjaga lingkungan disekitarnya melalui beberapa tindakan, selain itu berupaya mencegah terjadinya kerusakan lingkungan dan berupaya untuk memperbaiki suatu lingkungan yang telah rusak. Dalam hal ini, untuk membentuk karakter peduli lingkungan diharapkan ditanamkan sejak usia dini.
Terdapat beberapa indikator yang harus dicapai oleh sekolah dalam rangka menanamkan pendidikan karakter peduli lingkungan. Menurut Fathurrohman, Pupuh dkk, (2013:191) indikator pendidikan karakter peduli lingkungan berupa :

1. Pembiasaan memelihara kebersihan dan kelestarian lingkungan sekolah.

2. Tersedia tempat pembuangan sampah dan tempat cuci tangan.

3. Menyediakan kamar mandi dan air bersih.

Pendidikan karakter peduli lingkungan apabila telah tertanam pada diri peserta didik dapat dibuktikan melalui keberhasilan indikator yang telah di capainya. Menurut Narwanti (2011:69) indikator yang harus di capai dan tertanam dalam diri siswa sebagai ciri bahwa karakter peduli lingkungan telah tertanam dalam lingkup kelas yaitu: kebersihan ruang kelas, menyediakan tempat sampah organik dan anorganik, hemat dalam penggunaan bahan praktik, dan penanganan limbah bahan kimia dari kegiatan praktik.

Dalam menentukan suatu keberhasilan pendidikan karakter peduli lingkungan terdapat beberapa komponen pendukung. Menurut Wiyani, Novan, Ardy (2012:40-50) menjelaskan bahwa dalam pelaksanaan pendidikan karakter peduli lingkungan terdapat lima komponen yang mendukung keberhasilannya, yaitu kurikulum, pengelolaan, pembiayaan, guru, dan siswa.

\section{Program Mari Buang Sampah Pada Tempatnya (Marbungsamtem) \\ Program merupakan suatu} pernyataan yang berisi beberapa rancangan yang diharapkan rancangan tersebut dapat 
dijalankan dengan baik dan mencapai suatu tujuan yang diharapkan.

Program Mari buang sampah pada tempatnya merupakan suatu pembiasaan yang dilakukan dengan memerintahkan siswa untuk membawa kantung plastik dari rumah. Kantung plastik tersebut guna nya agar siswa dapat membuang sampah milikinya pada kantung plastik yang di bawa. Selain itu, di SDN Taman Ciruas Permai tidak di sediakan tempat sampah. Latar belakang diadakannya program tersebut yaitu kebiasaan siswa yang tidak disiplin dalam membuang sampah, banyaknya penumpukan sampah yang terjadi di sekolah, dan mengurangi sampah yang berasal dari sekolah. Selain siswa yang diminta untuk membawa kantung plastik untuk membuang sampahnya, tetapi pedagang di kantin sekolah juga diminta untuk membawa kantung plastik untuk membuang sampah dari hasil dagangannya.

\section{Manfaat Program Mari Buang Sampah Pada Tempatnya}

Program Mari buang sampah pada tempatnya di adakan untuk membiasakan siswa membuang sampah pada tempatnya. Namun disini, tempat sampah berasal dari siswa sendiri berupa kantung plastik yang dibawa oleh siswa untuk mengumpulkan sampah yang dimilikinya, kemudian di buang ketika pulang sekolah di rumah siswa masing-masing. Sekolah tidak menyediakan tempat sampah.

Dengan adanya program Mari Buang Sampah Sama Tempatnya (Marbungsamtem) membuat lingkungan di SDN Taman Ciruas menjadi bersih, tidak ditemukan sampah. Melalui program ini, diharapkan peserta didik akan menjadi pribadi yang terbiasa disiplin dalam membuang sampah dan peduli terhadap lingkungan di sekitarnya. Hal ini juga sesuai dengan pernyataan Fanam (dalam Ninsih, dkk 2018:75) bahwa salah satu kunci kesuksesan dalam rangka membangun karakter yang baik dalam diri anak didik adalah setiap rangka membiasakan karakter yang akan dibentuk.

\section{METODE PENELITIAN}

Penelitian ini menggunakan metode deskripsi dalam pendekatan kualitatif. Menurut Sugiyono (2017:63), Metode deskriptif merupakan suatu metode dalam meneliti status sekelompok manusia, suatu objek, suatu kondisi, suatu sistem pemikiran ataupun suatu kelas peristiwa pada masa sekaarang. Penelitian deskriptif bertujuan untuk membuat deskriptif yang dibuat secara sistematis, faktual, dan akurat tentang fakta-fakta yang berhubungan dengan fenomena yang diselidiki. Lokasi penelitian yang digunakan berada di dua tempat yakni di lingkungan SDN Taman Ciruas Permai dan lingkungan rumah siswa perumahan Taman Ciruas Permai. Prosedur pengumpulan data disini menggunakan 3 teknik mulai dari observasi, wawancara, dan dokumentasi.

\section{HASIL DAN PEMBAHASAN}

Peneliti sebelumnya terlebih dahulu melakukan observasi, wawancara, dan dokumentasi. Terdapat kegiatan harian dan mingguan yang dilakukan di sekolah yang bertujuan untuk membentuk karakter peduli lingkungan pada siswa. Kegiatan harian yang dilakukan siswa di sekolah ini melalui program mari buang sampah pada tempatnya yaitu membawa kantung plastik dari rumah dan membuang sampah pada plastik yang sudah mereka bawa. Selain itu 
siswa di sini juga dibiasakan ketika melihat sampah tergeletak di lingkungan sekolah harus segera di ambil. Mau itu sampah dirinya ataupun orang lain siswa dibiasakan untuk peduli terhadap lingkungan dengan membuang sampah yang tergeletak di jalanan, melepas sepatu ketika masuk ke dalam kelas, tidak makan di dalam kelas, serta piket kelas. Piket kelas di sini dilakukan setiap pagi sebelum belajar dan siang saat pulang sekolah. Piket yang dilakukan sebelum saat siang hari ini selalu diawasi atau ditemani oleh wali kelas agar melakukan piketnya dilaksanakan dengan benar dan bersih. Hal ini sejalan dengan pendapat Salihah $\mathrm{S}$, Salamah, S (2017: 164) lingkungan belajar yang nyaman dapat diciptakan pula dengan tersedianya sapu, papan tulis yang selalu bersih, memadukan warna-warna di ruangan kelas, dan penataan ruangan, kursi, dan meja yang bersih dan bebas dari corat-coret.

Kegiatan harian yang dilakukan siswa di rumah dalam proses pembentukan karakter peduli lingkungan pada siswa yaitu tidak beda jauh dengan kegiatan yang dilakukan siswa di sekolah. Pembiasaan di sekolah yang mengajarkan siswa untuk membuang sampah pada tempatnya, mengambil sampah yang terlihat di jalan, membersihkan kelas dengan menyapu, mengepel, dan mengelap jendela mampu diterapkan siswa di rumahnya. Jadi, setiap siswa selesai makan atau jajan pasti siswa akan membuang sampah bekas bungkusannya tersebut di tempat sampah. Hal ini sejalan dengan pendapat Nenggala (2007: 173) seseorang bisa di katakan memiliki sikap peduli terhadap lingkungan apabila : Menjaga atau memelihara kelestarian lingkungan yang ada disekitar, Selalu membuang sampah pada tempatnya., Melakukan atau melaksanakan kegiatan membersihkan lingkungan yang ada disekitar.

Selain kegiatan harian, terdapat kegiatan mingguan. Kegiatan mingguan yang dilakukan siswa disini yaitu kegiatan gotong-royong. Kegiatan yang dilakukan setiap hari Sabtu ini dilakukan dengan membersihkan lingkungan sekolah yang dilakukan dengan cara bergotong-royong bersama dengan kepala sekolah, guru, dan siswa. Dengan membersihkan lingkungan yang dilakukan dengan gotong royong akan membuat pekerjaan menjadi lebih cepat dilakukan. Hal ini sejalan dengan pendapat Soekarno, Koentjaraningrat (2013: 11) gotong-royong merupakan kegiatan yang dilakukan bersama-sama yang bertujuan untuk memenuhi kebutuhan dan menyelesaikan permasalahan secara bersama.

Setelah melakukan penelitian, terlihat hasil yang didapatkan setelah diadakannya program Marbungsamtem yang bertujuan untuk membentuk karakter peduli lingkungan. Dengan tidak adanya tempat sampah di sekolah membuat lingkungan sekolah menjadi bersih. Siswasiswi lebih peduli terhadap lingkungan disekitarnya dan lebih disiplin untuk membuang sampah pada tempatnya yaitu kantung plastik yang sudah dibawa oleh masing-masing siswa. Lingkungan sekolah yang bersih akan sangat bermanfaat bagi seluruh warga sekolah. Hal ini sejalan dengan pendapat Puastuti (2014: 4) bahwa dengan lingkungan sekolah yang bersih akan memiliki dampak yang baik dan pengaruh yang besar bagi siswa-siswi terlebih lagi bagi sekolah. Oleh karena itu kebersihan di lingkungan sekolah harus terus dijaga dan dirawat kebersihannya agar kegiatan apapun yang dilakukan di 
sekolah akan berjalan dengan nyaman dan baik.

Selain lingkungan yang bersih, hasil dari diadakannya program sekolah yaitu Marbungsamtem yang bertujuan untuk membentuk karakter peduli lingkungan pada diri siswa, mampu siswa terapkan pada lingkungan di rumahnya. Terlihat bahwa siswa di rumahnya masingmasing sudah terbiasa untuk membuang sampah pada tempatnya, menyapu lantai, mengepel lantai, dan menyapu halaman rumah. Hal ini terjadi karena pembiasaan yang secara terus menerus dilakukan membuat siswa menjadi terbiasa. Hal ini sejalan dengan pendapat Deni, K dan Suro, P (2010: 58) bahwa terbiasanya siswa dalam menjaga kebersihan lingkungan sekolah maka akan memiliki kebiasaan baik untuk menjaga kebersihan lingkungan dimana saja. Oleh karena itu dapat disimpulkan bahwa pembiasaan yang dilakukan di sekolah dengan baik akan mampu diterapkan pada lingkungan lain seperti di lingkungan rumah siswa.

Sementara itu, berdasarkan hasil penelitian yang dilakukan di sekolah dan rumah siswa terdapat faktor penghambat dan faktor penunjang. Faktor penghambat dari lingkungan sekolah misalnya anakanak terkadang masih suka lupa untuk membawa kantong plastik dari rumah, mereka terkadang sudah terbiasa disiapkan oleh orang tua untuk perlengkapan apa saja yang harus dibawa ke sekolah, salah satunya kantung plastik untuk tempat sampah mereka. Bukan hanya karena lupa, namun hal ini terjadi karena faktor dari lingkungan rumahnya seperti orang tua yang lupa juga menyiapkan kantung plastik tersebut, dan tidak adanya kantung plastik dari rumah siswa. Beberapa faktor tersebut yang biasanya menjadi hambatan dalam program mari buang sampah ada tempatnya. Hal ini sesuai dengan pendapat Aini, S (2017: 63) bahwa proses mengingat atau memori banyak dipengaruhi oleh beberapa faktor yaitu faktor individu, faktor objek, dan faktor lingkungan. Faktor penghambat dari rumah siswa yaitu siswa yang suka meniru temannya ketika buang sampah sembarangan. Usia siswa sekolah dasar yang masih suka meniru orang disekitarnya menjadi salah satu hambatannya. Hal ini sejalan dengan pendapat Hosnan, M (2016: 60) bahwa dalam kehidupan sehari-hari, seorang anak akan mencari suatu figure yang dapat ia lihat dan temui. Mereka kemudian meniru apa yang dilakukan dan dikenakan orang yang ingin dia tiru tersebut. Oleh karena itu dalam berperilaku setiap orang harus mampu memberikan contoh yang baik terhadap orang lain terutama anak-anak yang kemungkinan besar akan meniru perilaku seseorang yang dilihatnya.

Selain faktor penghambat yang ditemukan di sekolah dalam pembentukan karakter peduli lingkungan pada siswa, terdapat juga faktor penghambat yang ditemukan di rumah siswa. Faktor penghambat tersebut diantaranya siswa yang suka meniru temannya ketika buang sampah sembarangan. Usia siswa sekolah dasar yang masih suka meniru orang disekitarnya menjadi salah satu hambatannya. Hal ini sejalan dengan pendapat Hosnan, M (2016: 60) bahwa dalam kehidupan sehari-hari, seorang anak akan mencari suatu figure yang dapat ia lihat dan temui. Mereka kemudian meniru apa yang dilakukan dan dikenakan orang yang ingin dia tiru tersebut. Oleh karena itu dalam berperilaku setiap orang harus mampu memberikan contoh yang baik 
terhadap orang lain terutama anak-anak yang kemungkinan besar akan meniru perilaku seseorang yang dilihatnya. Selain itu sekolah juga menyediakan tanaman yang hijau dan segar di lingkungan sekolah. Hal ini sejalan dengan pendapat Wiyani (2013: 222) bahwa dalam membangun pendidikan karakter perlu situasi yang mendukung seperti terdapat toilet, lingkungan yang hijau dengan tumbuhan, serta slogan atau kalimat yang mengajak untuk peduli terhadap lingkungan, menjaga kebersihan, dan menjaga kesehatan diri yang ditempelkan di lingkungan sekolah. Faktor pendukung yang ditemukan di rumah siswa tidak beda jauh dengan di lingkungan sekolah. Pada lingkungan rumah siswa terdapat faktor pendukung berupa tersedianya beberapa tempat sampah di lingkungan rumah siswa, terdapat petugas kebersihan yang membuang sampah di tempat pembuangan sampah akhir, dan contoh perilaku orang dewasa disekitar rumah ketika membuang sampah pada tempatnya, Hal ini sejalan dengan pendapat Yanto, Murni, Syaripah (2017: 67) bahwa segala sesuatu yang dilihat oleh anak dalam kegiatan seharihari dapat ditiru atau dicontohkan oleh anak dan mempengaruhi perilaku anak tersebut.

\section{SIMPULAN DAN REKOMENDASI}

Berdasarkan hasil penelitian yang dilakukan peneliti di SDN Taman Ciruas Permai dan rumah siswa Taman Ciruas Permai dapat ditarik beberapa kesimpulan sebagai berikut :

1. Peneliti menyimpulkan bahwa hasil dari pembentukan karakter peduli lingkungan melalui program mari buang sampah pada tempatnya (Marbungsamtem) dianataranya lingkungan sekolah menjadi lebih bersih dan terawat, tidak adanya penumpukan sampah di sekolah, siswa terbiasa untuk membuang sampah pada tempatnya, siswa menjadi lebih peduli terhadap lingkungan di sekitarnya. Selain itu hasil yang didapatkan pada lingkungan rumah siswa yaitu siwa terbiasa untuk membuang sampah pada tempatnya karena pembiasaan di sekolah yang selalu membuang sampah langsung pada tempatnya, lebih peduli terhadap lingkungan di rumahnya, dan dengan terbiasanya siswa membersihkan ruang kelas membuatnya bisa membantu kedua orang tua membersihkan rumah dengan menyapu lantai rumah, menyapu halaman rumah, dan mengepel lantai rumah.

2. Faktor penghambat dalam pelaksanaan program mari buang sampah pada tempatnya (Marbungsamtem) dari lingkungan sekolah dan rumah siswa. Faktor penghambat yang didapatkan dari lingkungan sekolah yaitu siswa yang terkadang masih lupa untuk membawa kantung plastik dari rumah sehingga terkadang membuang sampah di kantung pakaiannya dan tas siswa tersebut. Dari lingkungan rumah faktor penghambatnya berupa masih terdapat teman siswa yang membuang sampah sembarangan ketika selesai jajan sehingga dapat membuat siswa mencontoh perilaku tersebut.

3. Faktor pendukung dalam pelaksanaan program mari buang sampah tempatnya (Marbungsamtem) dari lingkungan sekolah dan rumah siswa. Faktor pendukung dari lingkungan sekolah yaitu orang tua siswa dan 
warga sekolah ikut mendukung pelaksaan program (Marbungsamtem) sehingga membantu lancarnya program ini dan tersedianya sarana dan prasarana yang lengkap seperti tersedianya tempat mencuci tangan di setiap kelas, alat kebersihan di sekolah yang lengkap, slogan-slogan yang mengajak menjaga kebersihan lingkungan yang di tempelkan di lingkungan sekolah, serta rak sepatu yang tersedia di setiap kelas. Faktor pendukung dari lingkungan rumah siswa yaitu tersedianya tempat pembuangan sampah di setiap rumah sehingga mempermudah setiap orang ketika akan membuang sampah, terdapat petugas kebersihan yang mengambil sampah dan membuang smapah tersebut ke tempat pembuangan akhir sehingga tidak terjadi penumpukan sampah, dan banyak orang dewasa yang memberi contoh membuang sampah pada tempatnya.

Dalam hal ini, peneliti memberikan beberapa saran bagi pembaca berdasarkan hasil penelitian 1) Kepala sekolah hendaknya membuat suatu program sekolah yang bertujuan untuk membentuk karakter pada siswa. Hal ini dilakukan karena pentingnya pembentuk pendidikan karakter pada siswa. Dengan adanya program sekolah akan memudahkan dalam pembentukan karakter pada siswa. 2) Guru hendaknya dapat menjadi contoh yang baik bagi siswa dalam berperilaku, sehingga siswa mampu mencontoh perilaku yang baik dari guru. 3) Orang tua siswa disarankan untuk selalu memantau kegiatan anaknya di sekolah, selalu bertanya apa yang dilakukannya di sekolah, kegiatan apa saja yang ada di sekolah, dan mendukung setiap kegiatan positif yang dilakukan di sekolah.

\section{DAFTAR PUSTAKA}

Ahmad, T. (2010). Filsafat Ilmu: Mengurangi Ontology, Epistemology, Dan Aksiologi Pengetahuan. Bandung: Remaja Rosdakarya.

Deni, K \& Suro, P. (2010). Pendidikan Jasmani, Olahraga Dan Kesehatan Untuk Kelas IV SD. Jakarta: Pusat Perbukuan Nasional.

Ihsan, F. (2010). Dasar-dasar Kependidikan Komponen MKDK. Jakarta: Rineka Cipta.

Komalasari, K. (2017). Pendidikan Karakter, Konsep Dan Aplikasi Living Values Education. Bandung: PT. Refika Aditama.

Narwanti, S. (2011). Pendidikan karakter. Yogyakarta : Familia.

Ninsih, dkk., (2018). Pendidikan Karakter

Peduli Lingkungan Melalui

Program "Mahira Bebas Sampah"

Di SD Alam Mahira Kota

Bengkulu, Jurnal Pendidikan Guru Sekolah Dasar, 1: 73-82.

Puastuti, D., (2014). Hubungan Antara

Persepsi Dan Sikap Terhadap

Lingkungan Hidup Dengan

Perilaku Siswa Mengenai

Kebersihan Lingkungan Sekolah Di

SDN Kemasan 1 Kota Surakarta

Tahun 2013/2014. FKIP.

Universitas Sebelas Maret.

Surakarta.

Sugiyono. (2017). Metode Penelitian

Kuantitatif, Kualitatif, dan $R \& D$.

Bandung:

CV Alfabeta.

Tatang. (2012). Ilmu Pendidikan. Bandung: CV. Pustaka Setia. 


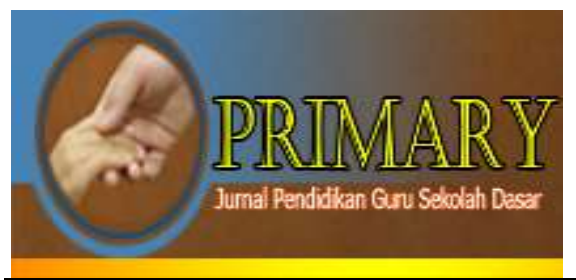
PRIMARY: JURNAL PENDIDIKAN GURU SEKOLAH DASAR
VOLUME 10 NOMOR 5 OKTOBER 2021
ISSN : 2303-1514 | E-ISSN : 2598-5949
DOI : http://dx.doi.org/10.33578/jpfkip.v10i5.8277
https://primary.ejournal.unri.ac.id/index.php/JPFKIP

Wiryani, N A. (2012). Pendidikan Karakter Berbasis Iman dan Taqwa. Yogyakarta: Teras.
Yaumi, M. (2014). Pendidikan Karakter: Landasan, Pilar, dan Implementasi. Jakarta: Predana Media Group. 